\title{
JENIS HIASAN TATAHAN BADE
}

\section{Made Suparta \\ Fakultas Seni Rupa dan Desain ISI Denpasar}

Abstrak

Penelitian tentang Jenis Hiasan Tatahan Bade bertujuan untuk mengetahu: (1) jenis motif pepatran maupun kekarangan yang diterapkan untuk menghias bangunan bade, serta urut-urutannya pada setiap palih/embakan karang; (2) jenis teknik ukiran/tatahan yang dipakai pada setiap motif pepatran/ kekarangan; dan (3) persaman dan perbedaan hiasan maupun tatahan yang ada pada setiap daerah yang dapat dijadikan sebagai ciri khasnya.

Motif hias yang beragam dan dijadikan motif bagian pada bangunan bade, tetap memiliki nilai sakral dan akan berlanjut semasih warna/kasta mentaati tradisi leluhurnya serta kewenangan yang diberikan oleh Dalem (raja). Dengan kata lain, semasih acara ngaben menggunkan sarana bade, motif hias dengan berbagai jenis dan bentuknya tetap diperlukan. Motif hias yang ada pada bangunan bade, memiliki hubungan hierarkis yang ganda sesuai dengan konsep desa kala patra. Penempatan motif hias yang ada pada bade adalah bentuk hubungan hirarkis horizontal di antara warna/kasta dalam agama Hindu terhadap Dalem (raja) atas penghargaan yang pernah diberikan.

Kata kunci: motif hiasan, upacara ngaben, dan tradisi leluhur

\section{PENDAHULUAN}

\section{Latar Belakang}

Motif hias sebagai salah satu karya seni rupa yang unik dan menarik dalam komonitas kecil, masih tetap menampakan eksistensinya khususnya di kalangan masyarakat Bali. Keberadaan motif hias ini sering menyertai berbagai bentuk kehidupan seni-seni lainnya, baik itu disatukan dengan seni lainnya maupun berdiri sendiri secara utuh. Dikalangan para perupa, motif hias yan memiliki garis ritmis dan penuh rutinitas sering dikatakan sebagai ornamen. Motif hias atau ornamen paling tidak sampai sat ini belum dapat banyak mendapat perhatian untuk dijadikan karya yang "utuh" kalau dibandingkan seni rupa lainnya. Bila kondisi ini terus dikondisikan, niscaya lambat atau cepat, seni yang naratif dan filosopis ini belum banyak mengalami perkembangan dalam artian seni ornamen tetap dijadikan bagian dari seni-seni lainnya. Pada sisi lainnya, seni hias/ornamen yang belum mampu berdiri sendiri ini, khusus di kalangan masyarakat Bali mampu menjadi karya yang "monomental" dan mewah bila diterapkan pada suatu bangunan. Lain kata, ornamen dijadikan sebagai pelengkap seni-seni lainnya.

Kontradiksi fungsi antara sebagai pelengkap dan kemandirian ornamen itu sendiri, paling tidak sampai saat ini belum adanya keinginan para pelaku untuk mengupayakan dan memformat seni hias/ornamen menjadi seni yang mandiri. 
Kesadaran berkesenian yang dimiliki masyarakat Bali, khususnya yang beragama Hindu Dharma, telah menjadi tradisi dan bagian yang tidak dapat dipisahkan dari kehidupannya. Tradisi berkesenian ini, tidak terlepas adanya pemikiran positif para kreator dengan mempolakan "rentang waktu" atau untuk kurun waktu tertentu. Cara-cara seperti ini dapat dilihat dari segi pola, kemanfaatan, tata tetak atau ruang bangun sesuai konsep desa kala patra yaitu: tempat. waktu, keadaan/ situasi Sebagai ilustrasi, sewaktu melakukan sesuatu pekerjaan kita diharapkan menyesuaikan dengan keadaan. Keadaan suatu pekerjan hendaknya dilihat dari waktu yang ada. Dan waktu bisa dijadikan salah satu barometer kualitas suatu pekerjaan. Masyarakat Bali yang sudah dikenal taat dalam melaksanakan kewajiban upacara "daur hidupnya", sering dihadapkan pada situasi yang bersamaan dan dihadapkan pada pilihan untuk diprioritaskan. Misalnya kegiatan upacara ngaben dan ngaben dadakan, dapat dan sering menjadi pertimbangan atau kendala guna melengkapi sarana maupun prasaran seperti karena diikat oleh keadaan dan waktu. Salah satu sarana yang "wajib" digunakan ketika melakukan upacara ngaben adalah bade atau wadah medasar bade (berpondasi bade).

Keterbukaan menyerap dan menerima pengaruh budaya luar yang selektif, dapat atau telah memperkaya benda budaya yang ada sebelumnya. Pengaruh seni dengan berbagai macam dan jenisnya, sampai saat ini "diterima" dan disesuaikan dengan kebutuhan. Adanya beberapa kali periode akulturasi pada masyarakat di Bali, telah memberi warna dan terjadinya periodisasi terhadap perkembangan kesenirupaan Bali.

Jenis-jenis motif yang terkait dengan hiasan sudah tentu bersumber pada ornamen, baik itu tentang macam, bentuk dan jenis ornament/pepatran yang "asli" Bali maupun pepatran yang kena pengaruh dari luar. Adapun yang dimaksud dengan macam ornamen ialah kekarangan, pepatran, kuta mesir, keketutan, dan wayang. Sedangkan untuk mengetahui tentang jenis dan teknik, digunakan pendekatan tentang cara atau metode memahat/menatatah dan jenisjenis peralatan yang digunakan.Dan untuk mengetahui nilai filosopis terhdap penempatan suatu motif hias akan menggunakan sosiologi dan antropologi seni.

Motif Hias dengan berbagai jenis serta penempatannyan pada suatu bangunan mempunyai teknik, pola dan material yang berbeda-beda. Secara filosopis motif hias juga suatu realita yang cukup problematik kalau dikaitkn dengan penempatanya di suatu bangunan. Menghindari luasnya wilayah penelitian dan melebarnya cakupan materi yang digunakan, kiranya perlu diberi suatu bingkai untuk membatasi masalah yang akan diangkat. Masalah yang akan diteliti pada kesempatan ini meliputi karya-karya Motif Hias serta fungsinya menjadi prioritas dalam penelitian ini. Adapun masalah-masalah yang muncul dalam penelitian "Jenis Hiasan Tatahan Bade" adalah: (1) mengapa Jenis Motif hias pepatran dan kekarangan banyak dijadikan hiasan bade, (2) jenis Motif hias apa saja yang dijadikan hiasan bade, dan (3) teknik ukiran yang macam apa diterapkan bade.

\section{Tujuan Penelitian}

Sesuai dengan tujuannya, dalam penelitian tentang Jenis Hiasan Tatahan

Bade ada beberapa jenis motif yang perlu untuk diketahui yaitu:

1) jenis motif pepatran maupun kekarangan yang diterapkan untuk menghias bangunan bade, serta urut-urutannya pada setiap palih/embakan karang,

2) jenis teknik ukiran/tatahan yang dipakai pada setiap motif pepatran/ kekarangan,

3) persaman dan perbedaan hiasan maupun tatahan yang ada pada setiap daerah yang dapat dijadikan sebagai ciri khasnya.

\section{Kajian Teori}

Untuk mendukung kelancaran penulisan dan penjelsan suatu karya ilmiah, sudah barang tentu tidak bisa lepas dengan pustaka-pustaka yang ada relevansinya terhadap judul yang telah ditentukan. Agar bisa memahami Motif Hias secara konseptual hendaknya perlu disadari dan dihayati keberadaan. Motif hias adalah salah satu bagian dari seni rupa. Sebagai hasil cipta seni, kehadiran Motif hias perlu pula dipandang sebagai bagian yang tidak terpisahkan dari keperluan seni bangunan dan hiasannya.

Menghindari penafsiran yang tidak jelas terhadap maksud maupun pengertian judul tersebut, "Motif Hias dan Jenis-Jenis Ukiran Bade", akan diuraikan kata demi kata agar mendapatkan sebuah pengertian yang lebih valid. Adanya beberapa bhisma atau kewajiban yang diwariskan secara turun-temurun terhadap generasi penerusnya khususnya dalam penggunaan Bade oleh masyarakat Hindu Dharma di Bali, dapat memperkaya keragaman bentuk, tingkat/ tumpang, jenis motif dan penempatannya.

Dalam Kamus Besar Bahasa Indonesia kata motif adalah pola; corak atau gagasan dominan dalam karya sastra. Hias sendiri mempunyai pengertian indah, jadi dapat dikatakan hias atau hiasan adalah suatu barang atau benda yang bertujuan untuk memperindah suatu benda. Dalam hal penelitian ini yang dimksud dengan benda adalah bangunan bade yang merupakan usungan jenasah bagi umat Hindu di Bali.

Beraneka ragamnya penggunaan bentuk, jenis dan tumpang atau tingkat atap pada bangunan bade telah tertuang dalam beberapa babad yang sampai saat ini masih dipercaya dan dipakai oleh masyarakat Hindu Bali yang digolongkan menjadi empat warna/ kasta. Ukiran adalah hasil dari torehan, goresan, pahatan, (KBBI). Dalam seni kriya, ukiran adalah hasil pahatan yang masih dapat di kelompokkan lewat dedalaman teknik,seperti teknik tembus, cekung dan 
cembung. selain Masing-masing teknik ini mempunyai ciri masing-masing, seperti ada pada bagian motifnya yang hilang, ada pula bagian isiannya yang dihilangkan. Kriya yang kaya dengan teknik dan material tersebut juga masih dapat dibedakan jenisnya kalau di terapkan pada teknik tatahan media kulit maupun kertas. Kehalusan suatu ukiran/tatahan sangat dipengaruhi oleh alat maupun bahan yang digunakan.

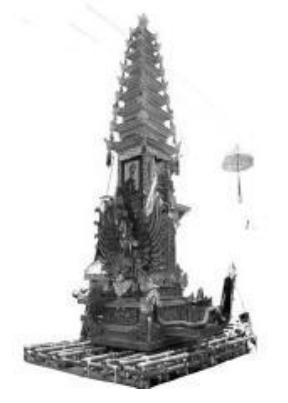

Foto No. 1 Bade Tingkat 9, tampak dari belakang, saat Pelebon di Puri Karangasem. (Dokumen Penulis)

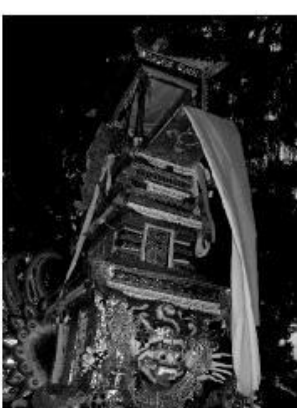

Foto No. 2. Wadah berpondasi Bade (tingkat 1) tampak dari depan, di Payangan Gianyar. (Karya Penulis)

Motif Hias sebagai material kultur, tidak cukup hanya diberi perhatian/ perlindungan. Kreativitas yang inovatif untuk mengantisipasi perubahan di masa mendatang, menjadi tanggung jawab para undagi/sangging untuk mengembangkan seni (Motif Hias) perlu dipacu sesuai dengan tuntutan masyarakat, seperti diungkapkan Van der Hoop, generasi kini diharapkan mencari dan mengupayakan penciptaan karya seni baru sesuai dengan jiwa zamannya. (Van der Hoop, 1949).

Keberadaan motif hias tersebut tercermin dengan adanya ornamen simbol berupa kekarangan, pepatran, keketusan dan kutamesir serta motif hias tokoh Dewa, manusia, binatang, benda-benda alam lainnya yang dibuat secara dekoratif maupun surealistis. Dalan artian, seni-seni maupun unsur-unsur budaya yang berkembang di Bali saling terkait dan mendukung. Analisis makna simbol dan dalam suatiu mite/mitologi, memerlukan pendekatan struktural untuk mengungkap persamaan dan perbedaan mite sebagai bahasa visual. Sudah barang tentu pendekatan multidisiplin dapat membantu dalam menganalisis, mengumpulkan data kualitatif, penentuan populasi dan sampel serta metode verstehen, yaitu pendalaman secara sosial, kultural dan psikologis, bahkan sosiolinguistik (Soedarsono, 1999).

Korelasi antara motif hias sebagai sarana keagamaan dengan fungsi bangunan bade adalah hal penting yang tidak dapat diabaikan, seperi dikemukakan oleh I Made Susila Patra, bahwa untuk menciptakan karya berupa Motif Hias, baik itu sebagai sarana keagamaan maupun keperluan wisatawan, makna filosopis serta ketekunan dan keuletan adalah modal utama untuk melahirkan karya berkualitas. Keterampilan teknis perlu dikuasai oleh para undagi, seniman, perajin, berikut penguasaan pengetahuan mengenai material, karena setiap material mempunyai sifat dan kegunaan yang berbeda-beda. Terlebih bahan dan motif digunakan untuk sarana keagamaan, tentu memerlukan upacara khusus yang dilakukan oleh seniman dengan perhitungan baik buruknya hari yang dipilih (Padewasan). (Susila Patra, I Made, 1992, p. 18)

Pembuatan dan penempatan motif hias pada bangunan yang berwujud bade, bukan saja dilihat dari keserasian, keindahan bentuk, halusnya ukiran/ tatahan, juga memperhatikan aturan berdasarkan norma, kepustakaan maupun mitologi yang diyakini keberadaannya. Levi Strauss melihat mite atau dongeng tidak ubahnya seperti fenomena bahasa, dan bahasa merupakan simbol yang digunakan untuk menyampaikan pesan-pesan. Karena mite merupakan sebuah cerita, maka hingga kini orang selalu mencari dan menggali pesan-pesan yang dianggap ada di balik mite tersebut. Salah satu hal penting yang membedakan mite dengan bahasa adalah isi dan susunan ceritanya, yang mempunyai ciri khas berupa sifat-sifat atau ciri-ciri mistisnya. (Oktavio Paz, 1997,pp. xxxiii-xxxv).

Perkembangan dan perubahan unsur-unsur serta susunan pada masingmasing gaya yang dimiliki Motif Hias dipahami lewat "gaya" sebagai kreteria untuk memudahkan pengklasifikasian berdasarkan lokasi/tempat, periodisasi serta keadaan serta pandangan-pandangan para undagi/seniman (Desa, kala, patra). Terkait dengan judul " Motif Hias dan Jenis-Jenis Ukiran Pada Bangunan Bade" perlu pula meninjau pustaka-pustaka yang kiranya dapat dijadikan pegangan ataupun landasan untuk mengetahui seluk beluk Motif hias. Pustaka-pustaka yang digunakan antara lain, I Wayan Sika, Gusti nyoman Sudara. 1979. Mengenal Motif Hias Ni Made Kadjeng, Tim Penuyusun Monografi Daerah Bali, 1976. Monografi Daerah Bali, Jakarta. Pengembangan Media Kebudayaan. Direktorat Jenderal Kebudayaan Departemen Pendidikan dan Kebudayaan. 
Purnata, P. MD. 1976/1977. Sekitar Perkembangan Seni Rupa Bali, Denpasar: Proyek Sasana Budaya, Bali. D. Jensen, Gonrdon, Suryani Luh Ketut, 1996, Orang Bali, Bandung, Institut Teknologi Bandung. Daeng Hans, J. 2000, Kebudayaan Dan Lingkungan, Tinjauan Antropologi, Yogyakarta. Pustaka Pelajar. Dherana, Tjokorda Raka, 1976. Sekilas Tentang Desa Tenganan Pegringsingan, Denpasar. Fakultas Hukun Universitas Udayana. Dillistone, F. W. 2000. Daya Kekuatan Simbol, The Power of Simbol, (Terjemahan: A Widyamartaya) Yogyakarta. Kanisius. Piaget, Jean. 1996. Strukturisme, (Terjemahan: Hermoyo), Jakarta: Yayasan Obor Indonesia. Rantaesih Maulana, 1997. Ikonografi Hindu, Jakarta, Fakultas Sastra Indonesia dan Referensi/Pustaka lainnya yang terkait dengan judul.

\section{HASIL PENELITIAN DAN PEMBAHASAN}

\section{Jenis Ragam Hias}

Menciptakan karya seni berupa motif hias, apapun bentuk dan fungsinya, ketekunan dan keuletan adalah modal untuk melahirkan karya-karya yang berkualitas. Selain ketrampilan teknis yang perlu dikuasai para kriyawan dan pekerja seni, bekal materi dan pengetahuan material juga tidak kalah pentingnya, karena setiap material mempunyai sifat dan kegunaan yang berlainan. Material yang digunakan untuk sarana keagamaan tidak hanya dilihat dari kualitas bahan itu sendiri, tetapi juga tentang tempat pengambilan bahan, hari baik memulai pekerjaan, kelengkapan sesaji, dan siapa yang mengerjakan. Semua itu merupakan rangkaian proses dan tahapan-tahapan yang perlu disertakan.

Seni kriya tidak lepas dari unsur-unsur motif maupun pola sebagai elemen dasar pembuatan ornamen/hiasan, penempatan, dan kesesuaian mengikuti bidang/ ruang guna terciptanya keharmonisan. Ditinjau secara kronologis kegiatan hiasmenghias maupun penggunaan motif hias, berdasarkan sifatnya yang ada, dapat digolongkan menjadi 4 (empat). Pertama kategori primitif (prasejarah), kedua kategori klasik (mulai dikenalnya tulisan), ketiga kategori tradisional (zaman Madya) dan terakhir kategori modern (praktis, ekonomis, dan efisien). Pada dasarnya semua karya/benda seni kriya digunakan sebagai pemenuhan kebutuhan manusia, baik secara jasmani maupun rohani sesuai zamannya. Walaupun pengambilan motif dan penggunaan pola ditampilkan secara sederhana, dalam perkembangan selanjutnya, motif hias maupun pola-pola yang diterapkan dalam seni kriya menurut fungsinya dapat dibedakan menjadi tiga. Pertama yang tergolong kriya seni sebagai media tersalurnya gagasan estetik, kedua yang tergolong kriya fungsional sebagai sarana pemenuhan kebutuhan hidup sekaligus mengandung elemen estetis, dan ketiga yang tergolong kriya fungsional konstruktif merupakan simbolisasi dan perwujudan cita-cita luhur.

\section{Ragam Hias Keketusan}

Motif keketusan adalah hasil stilisasi bentuk tumbuh-tumbuhan, binatang, dan benda alam lainnya. Keketusan dibuat dengan menyusun secara berulangulang, dengan pola dan motif yang sama, guna menemukan satu kesatuan. Walaupun dibuat ecara berantai, namun antara motif yang satu dengan motif lainnya kelihatan ada pemisah secara jelas/tajam, dapat berdiri sendiri (satu motif), dan tidak memiliki tangkai yang menghubungkan seperti pada pepatran.

Motif keketusan sebagai salah satu motif yang mendominasi hiasan bangunan bade dan hampir ada pada setiap palih mempunyai ukuran relatif lebih kecil. Penempatan motif keketusan ini ada pada setiap tias, baik itu pai maupun tias ganggong
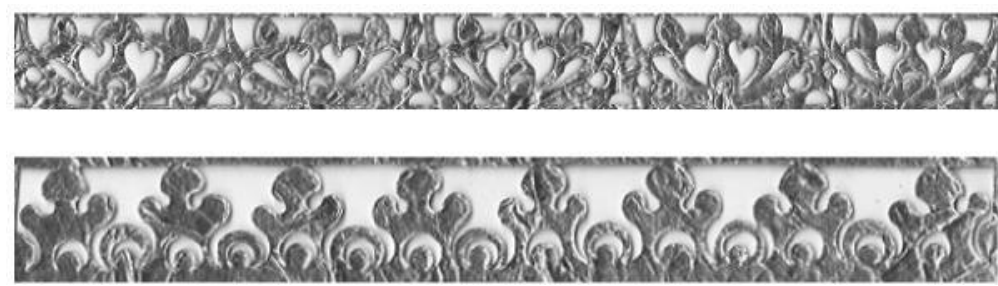

\section{Gambar No. 3. Motif hias kapu-kapu dan batu-batuan.}

(Tatahan: I Made Suparta)

Penggunaan Jenis keketusan yang beragam ini biasanya disesuaikan untuk mendapatkan keserasian dan berdasarkan besar- kecilnya ukuran tias. Seandainya pada palih bukur menggunakan kakul-kakulan atau mas-masan, pada palih taman/karang taman digunakan kapu-kapu atau yang lainnya. Teknik ini digunakan untuk menghindari kesan menetun yang membosankan.
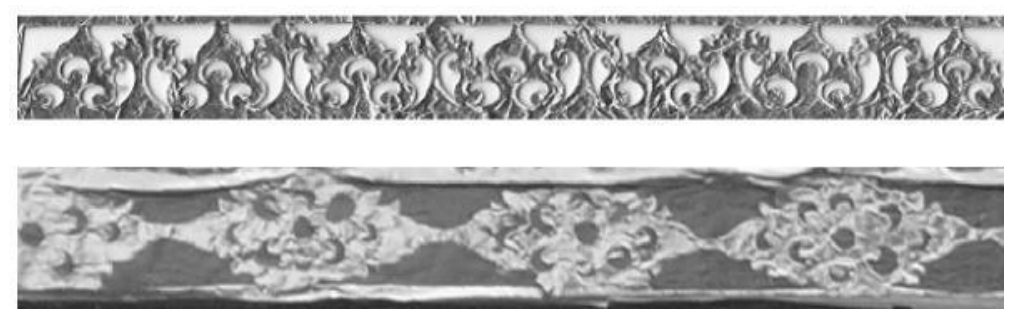

Gambar No. 4. Motif Kuping Guling dan mas-masan.

(Tatahan: I Made Suparta)

Jenis-jenis keketusan ini seperti: kakul-kakulan yang merupkan stilisasi dari keong, batu-batuan, dari batu, pid-pid dari pakis, dan batun timun stilisasi dari biji mentimun serta mas-masan merupakan stilisasi dari kepingan bunga emas. 
Motif hias mas-masan pada beberapa tempat/palih pada bangunan bade dijadikan pusat perhatian atau ukurannya diduat lebih besar. Mas-masan juga ditempatkan pada bagian pelok. Sedangkan hiasan kakul-kakulan ditempatkan pada bagian tepi pada bagian pelok. Tidak jarang pula motif ini digunakan sebagai pemanis/bingkai dari pepatran.

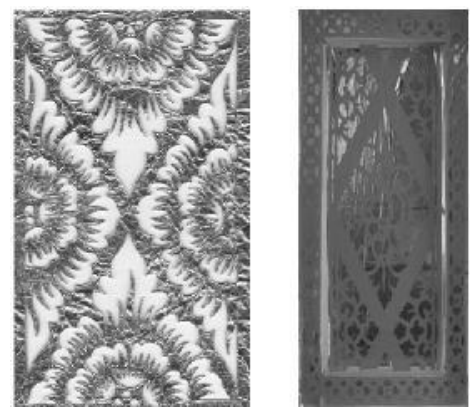

Gambar No. 5. Motif mas-masan sebagai hiasan pelok.

(Tatahan: I Made Suparta)

\section{Ragam Hias Temesir}

Motif temesir adalah motif hias yang menggunakan unsur-unsur garis lurus dengan berbagai ukuran, seperti tegak lurus (vertikal), mendatar (horizontal), dan miring. Semua unsur-unsur itu ditata/dirangkai secara terpadu sesuai dengan struktur yang diinginkan seperti berbentuk huruf T, L, tapak dara, dan swastika. Kombinasi semua unsur itu tertata dengan posisi arah biner, membuat motif hias temesir banyak dijadikan perlambang dalam keagamaan maupun menentukan tujuan hidup melalui pilihan-pilihan yang ada. Motif hias yang hanya menggunakan elemen-elemen garis lurus ini, lebih mengutamakan bentuk dan penyesuaian bidang yang bersifat ilmu ukur. Tersusunnya suatu bentuk motif geometris, dan komposisinya ditentukan berdasarkan atas fungsi.

Susunan garis vertikal dan horizontal dengan panjang yang sama, di Bali disebut tapak dara, sebagai tanda kehidupan yang terbentuk oleh unsur positif dan negatif. Begitu juga motif swastika yang dijadikan lambang Agama Hindu Dharma, mempunyai susunan motif yang nyaris sama seperti tapak dara, tetapi yang membedakan adalah pada keempat ujungnya disambung dengan garis yang searah dengan putaran jarum jam. Motif swastika dibuat dalam dua bentuk yaitu bentuk tunggal dan diberangkai, tidak dirangkai dalam suatu himpunan seperti yang difungsikan sebagai hiasan.

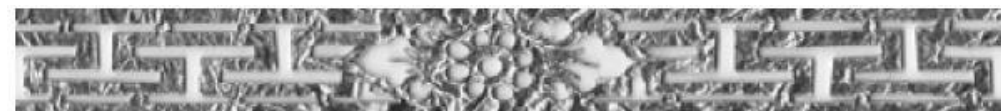

No. 6. Motif hias Temesir bentuk $L$ dan $T$.

(Tatahanr: I Made Suparta)

Dalam seni tradisional, motif hias tapak dara, mempunyai makna simbolis yang menggambarkan lima kekuatan dunia yang bersumber dari lima arah penjuru mata angin, yakni Utara, Timur, Selatan, Barat, dan Tengah sebagai pusat. Disebut tapak dara atau hiasan tapak kaki burung dara, karena bentuknya mirip/menyerupai telapak kaki burung dara. Dalam perkembangan lebih lanjut, motif hias tapak dara dikombinasikan dengan menyisipkan motif-motif keketusan untuk memberikan perimbangan terhadap garis-garis yang tegas, kaku, dan monoton. Kesederhanaan bentuk motif hias temesir ditata secara monotun, berjajar dan berulang-ulang, disesuaikan dengan keinginan. Motif ini sering dipadukan dan divariasikan dengan motif hias lainnya. Pada bidang-bidang tertentu seperti pada bingkai/pigura motif ini dapat berdiri sendiri
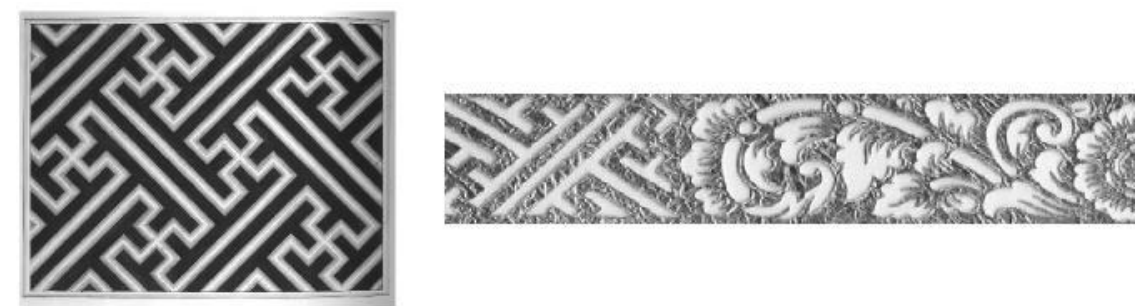

No.7. Motif hias temesir Swastika yang dirangkai.

(Gambar/tatahanr: I Made Suparta)

Kesederhanaan bentuk yang dimiliki motif hias ini dapat menimbulkan dan memancing daya tarik untuk tetap diperhatikan. Temesir yang memiliki unsur motif paling sedikit, sekaligus dijadikan elemen-elemen dasar kesenirupaan, eksistensinya dapat dikatakan sudah mengglobal. Kiat-kiat pelestarian motif hias temesir tidak saja menggunakan media yang umum digunakan oleh para perupa, namun dapat juga dilihat dan dinikmati pada sebungkus roti. Ornamen yang berasal dari kata ornare (Bahasa Latin) mengandung arti menghiasi, digunakan pada dimensi ruang atau bidang dengan fungsi yang berbeda. (I Gusti Nyoman Sudara dan I Nyoman Nikanaya, 1983), 6).

Oleh masyarakat Hindu Dharma Bali hiasan-hiasan tersebut diterapkan pada bangunan baik yang sifatnya sementara maupun permanen. Ornamentasi pada bangunan serta sifat yang dimilikinya, mempunyai keterkaitan erat pada 
situasi dan kondisi (iklim). Untuk mendukung semua itu, proses pengerjaan juga harus disesuaikan kepantasannya. Di beberapa tempat, dengan berbagai pertimbangan, pelaksanaan proses kerja kadang kala tidak dilalui sebagaimana mestinya. Sebagai contoh, bangunan di tempat-tempat terbuka seperti candi yang memiliki ukuran besar, pada tahap akhir sering tidak dilakukan, yaitu nyawi dengan maksud agar tidak cepat susut/aus dari terpaan angin dan cucuran air (faktor cuaca), serta enak dan jelas untuk dipandang dari jarak pada ketinggian tertentu.

Ditinjau dari relasi-relasi yang memiliki motif hias Bali, menurut Tim Ahli Penelitian dan Pencatatan Kebudayaan Daerah Bali, dapat dibedakan menjadi tiga. Pertama motif hias yang berkaitan dengan sistem kepercayaan, kedua motif hias yang berkaitan dengan upacara adat, dan ketiga motif hias yang berkaitan dengan aktivitas sehari-hari. (Tim Ahli Penelitian dan Pencatatan Kebudayaan Daerah Bali, 1977:124-125).

Motif hias yang terkait dengan kepercayaan dapat dilihat dari peninggalan zaman Megalitikum dengan sifat monumentalnya, sedangkan yang terkait dengan upacara adat, banyak dan sering nampak pada upacara manusa yadnya (daur hidup), mulai dari upacara magedong-gedongan yaitu upacara bayi semasih dalam kandungan sampai dengan pengabenan. Relasi moif hias dalam upacara ini, ada yang sama seperti relasi pertama, yaitu sebagai perlambang, pada sisi lain, banyak dijadikan sebagai perumpamaan seperti ketika mengadakan upacara ngakulin (tiga bulan kalender Bali) dengan pusuh (bunga pisang) diumpamakan sebagai saudara si bayi. Kalau dilihat dari kacamata rupa, sama sekali tidak menampakkan atau mirip orang-orangan, karena bunga pisang cuma dihias dengan kain tanpa diberi hiasan mata, hidung maupun mulut. Berbeda dengan pretima, yang dijadikan personifikasi para Dewa, kerupaannya terlihat dengan jelas walaupun itu sebagai stilisasi antropomorfisme. Motif hias yang ada hubungannya dengan aktivitas sehari-hari, tidak dijelaskan penyebab perbedaan relasi-relasinya, apakah sebagai keutuhan motif, tata cara pelaksanaannya, atau sarana yang digunakan.

\section{Ragam Hias Patra}

Dalam Kamus Bali Indonesia disebutkan bahwa patra adalah motif hias yang berpolakan dan mempunyai ciri-ciri sesuai dengan flora dan fauna yang distilisasi. Patra cina mempunyai ciri-ciri batangnya merambat, bunga bundar diapit tiga helai daun. Patra ulanda mempunyai komposisi statis antara pola batun poh, ampas nangka, kuping guling, janggar siap, dan kepitan. ${ }^{1}$ Dalam kamus ini tampaknya Tim Penyempurnaan kurang memahami secara mendetail perbedaan istilah antara motif, unsur motif, dan pola. Pola batun poh yang ada dalam motif hias patra punggel tidak sebagai pola. Kedudukannya adalah sebagai salah satu unsur yang diakumulasikan dengan unsur-unsur motif lainnya. Patra yang juga sering disebut pepatran adalah hasil stilisasi dari tumbuh-tumbuhan yang hidup merambat, menjalar maupun berdiri tegak, termasuk yang menghasilkan buah, bunga dan daun. Posisi pe pada kata patra menunjuk pada sifat yang dimiliki oleh tumbuh-tumbuhan dan binatang yang distilisasi kemudian distrukturisasikan sehingga terbentuk sebuah motif hias. Adapun jenis-jenis pepatran tersebut antara lain patra punggel, patra cina, patra ulanda, patra samblung, patra ertali, patra banci, dan patra sari.

Patra Gina lebih banyak menonjolkan variasi bunga dan tangkai ketimbang daun. Pada pola maupun bidang yang kosong diisi unsur motif berupa util, dengan maksud tidak ada bidang yang sepi/renggang. Patra cina sering dijadikan sindiran bagi orang yang senang mencuri, sebab pada setiap ruang/ bidang yang kosong selalu harus ngutil, maksudnya diberi/diisi util.

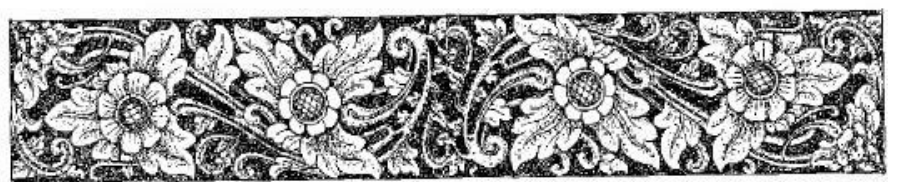

\section{No. 8. Motif hias patra cina.}

(Gambar: I Made Suparta)

Pada karya jenis ukiran, patra ini dikerjakan dengan teknik krawang/cekung, sehingga berbentuk bunga, tangkai, dan util sungguh-sungguh kelihatan jelas dan berlapis-lapis/bertingkat-tingkat. Patra cina adalah sebuah patra yang mempergunakan pola segi tiga memiliki banyak tangkai maupun cabang. Patra ini terdiri dari bunga yang sedang mekar atau kuncup, dipadukan dengan daun runcing, dan util.

Patra Ulanda adalah patra yang mendapat pengaruh dari Belanda. Patra ini tidak jauh berbeda dengan patra-patra lainnya, terutama dalam hal susunan polanya, kecuali mempunyai unsur motif yang lebih besar (beloh), pada ujungujung daun dibuat tumpul, menggunakan tangkai tunggal. Patra ini mempunyai atau dibuat dengan ukuran pola dan unsur-unsur motif yang lebih besar dibandingkan jenis patra lainnya, sehingga nampak tidak rumit. Dalam bangunan bade, patra ini kerap menghiasi bidang yang agak leber seperti pelok dan bagian bebaturan. Patra ini terdiri dari unsur daun, tangkai, kepitan, util besar/kecil dan bentuk bunga yang bulat. Patra ulanda terdiri dari daun susun/biasa (tunggal), kepitan dengan util yang besar yang digayam pada ujung/puncak motif. 


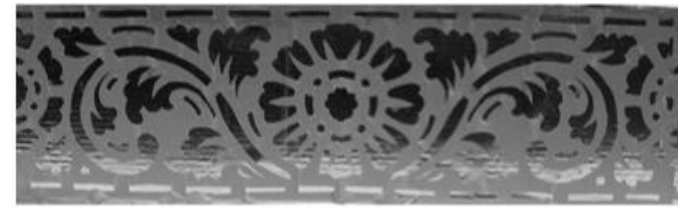

No. 9. Motif Hias Patra Ulanda.

(Tatahan: I Made Suparta)

Patra sambung adalah patra yang mempunyai unsur motif yang paling sedikit, tidak bertangkai dan sederhana di antara patra yang ada di Bali. Patra samblung adalah patra yang dibuat dengan pengulangan-pengulangan motif kepitan tanpa adanya suatu motif penyela. Motif hias ini sangat jarang ditemukan dalam bangunan bade. Secara teknis,motif hias ini ditatah dengan teknik pepradan.

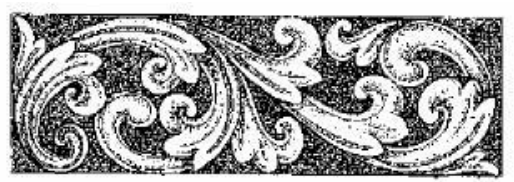

No. 10. Motif Hias Patra Samblung.

(Gambar: I Made Suparta)

Selanjutnya adalah patra ertali. Jika pada patra samblung mempunyai unsur motif yang paling sedikit, makna patra ertali mempunyai bentuk yang paling sederhana, hanya menonjolkan tangkai. Masih diragukan adanya pendapat atau tulisan-tulisan sebelumnya, yang mengatakan bahwa patra ertali itu mendapat pengaruh dari Itali. Jika dilihat dari bentuknya, yang seolah-olah cuma berupa tangkai, patra ertali itu lebih cenderung sebagai stilisasi tali, yang biasa dibuat untuk mengikat hewan dan benda lainnya, terdiri dari bunga, daun, dan tangkai.

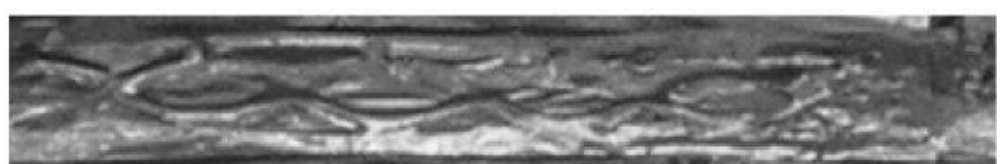

No. 11. Motif Hias Patra Ertali.

(Tatahan: I Made Suparta)

Patra banci adalah penggabungan dari beberapa unsur motif yang disesuaikan dengan keinginan para seniman/perajin yang membuatnya, yang paling penting dalam pembuatan patra ini adalah menyesuaikan dengan bidang yang ada. Patra banci kadang kala diciptakan dengan pendistorsian patra-patra yang ada seperti patra atau cina. Distorsi patra punggel seperti pada gambar. no. 12 ini dijdikan hiasan pelok pada wadah berponsasi bade di daerah payangan Gianyar. Distorsi patra punggel ini nyaris seperti api-apian atau dalam tatah wayang kulit disebut bias membah.

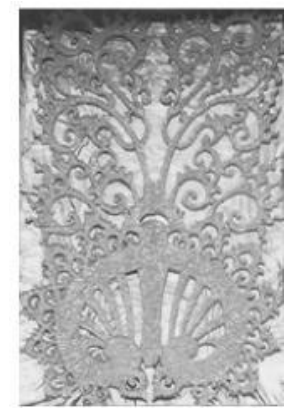

\section{No.12. Motif Hias Patra Banci.} (Tatahan: I Made Suparta)

Di antara patra-patra yang ada dan berkembang di Bali sampai saat ini, patra punggel adalah jenis patra yang memiliki identitas sebagai patra asli Bali. Asumsi ini didasarkan pada nama-nama unsur motif yang membentuknya yaitu gabungan stilisasi binatang dan tumbuh-tumbuhan yang hidup dan tumbuh di Bali.

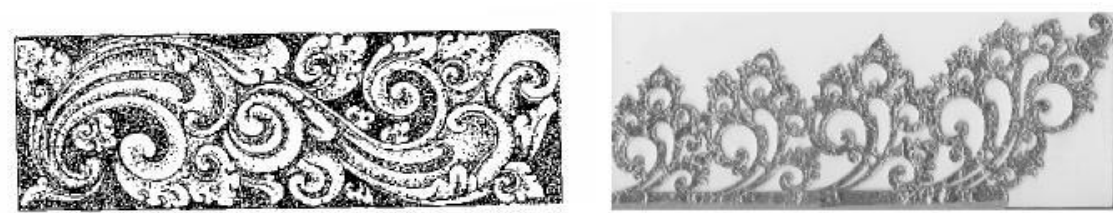

No. 13. Motif Hias Patra Punggel.

(Gambar/tatahan: I Made Suparta)

Terkait dengan penelitin ini, penggunaan patra punggel ini secara utuh dipakai pada puncak bangunan bade yaitu atap. Hiasn atap atau raab yang bertingkat-tingkat tersebut pada setiap sudutnya disebut dengan dore atau pemugbug, dan pada bagian yang paling atas disebut dengan bentala.

Adapun unsur-unsur motif tersebut adalah ampas nangka, batun poh (biji mangga), kepitan, util, janggar siap (jengger ayam), dan kuping guling (telinga babi guling).

Patra sari adalah jenis patra berbentuk bunga yang dibuat dengan menyusun patra punggel secara simetris, dan ditengah-tengah kesimetrisannya itu 
dibuat bunga yang mirip dengan bentuk batu-batuan sebagai pusatnya. Simetrisnya penempatan patra punggel yang divariasikan, tidak saja disebelah kiri dan kanan, namun juga pada bagian atas dan bawah.

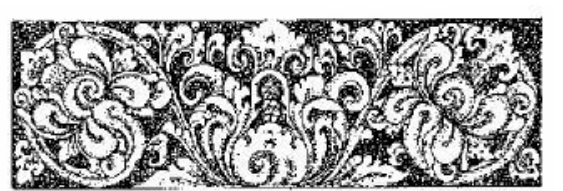

\section{No. 14. Motif Hias Patra Sari.}

(Gambar: I Made Suparta)

Patra ini juga menggunakan tangkai, serta daun berupa patra punggel yang tidak lengkap, atau hanya kuping gulingnya saja. Tangkainya dibuat melingkari bunga atau sama sekali lurus, seperti tangkai bunga lotus. Patra ini biasa digunakan untuk menghiasi pementang dan "muka" tiang bale dangin (timur) yakni bangunan yang biasa digunakan untuk keperluan upacara manusa yadnya. Dilihat dari segi unsurnya, patra sari ini sangat bagus dan harmonis untuk menghias pada setiap palih bangunan bade. Karena hampir semua motif menggunakan bahan kertas, motif yang penuh dengan tangkai dan bunga ini dikuatirkan robek ketika ditatah maupun dalam pemasangannya. Motif ini akan sangat indah kalau menghiasi pada bagian pelok.

\section{Ragam Hias Kekarangan}

Karang sebagai kata dasar yang mengandung pengertian tempat, mempunyai arti berbeda kalau diberi awalan ke- dan akhiran -an. Dari kata karang, kemudian menjadi kekarangan, mengandung arti rekaan atau karangan yang tidak sepenuhnya benar walaupun validitasnya tetap diakui. Kevaliditasan rekaan dalam menstilisasi fauna, flora, dan alam benda yang tidak bergerak, yang dijadikan motif hias adalah suatu yang sesuai apa adanya

Bade sebagai salah satu bangunan permanen namun mempunyai sifat sementara mempunyai jenis kekarangan yang relatif lengkap dibandingkan jenis bangunan lainnya. Kelengkapan ini dapat dilihat dari semua jenis binatang yang ada di tiga dunia seperti dunia atas, tengah dan bawah. Selain menggunakan hiasan seperti karang guak, tapel bentulu, dan karang asti juga menggunakan wujud paksi/garuda dan bhoma. Bentuk ini dapat dikatakan istimewa, karena dua hiasan ini selain ukurannya besar, juga mempunyai makna filosofis.

Alam beserta isinya, yang dijadikan inspirasi para seniman untuk membuat motif hias kekarangan, mengambil bentuk-bentuk binatang yang ada di tiga dunia, yaitu dunia atas, tengah, dan bawah. Ketiga dunia atau disebut juga Tri loka itu adalah bhur loka (dunia bawah), bhwah loka (dunia tengah) dan swah loka (dunia atas) yang mempunyai fungsi dan makna lambang tersendiri. Burung atau manuk dilambangkan sebagai penguasa dunia atas, manusia (topeng) melambangkan dunia tengah, dan gajah atau asti melambangkan dunia bawah.

Kepala, sebagai salah satu bagian anggota tubuh manusia maupun binatang, yang dianggap terpenting di antara bagian tubuh lainnya, digayakan/ stilisasi untuk dijadikan motif hias. Muka atau kedok dalam seni hias-menghias telah digunakan sejak zaman perunggu untuk menghiasi nekara, senjata, dan jenis-jenis bangunan ataupun benda-benda yang diyakini memiliki kekuatan gaib atau sakti. (Van der Hoop, 1949:100).

Penggambaran kedok/bagian muka untuk menghias suatu benda, tidak saja terbatas pada manusia, namun terjadi totem binatang yang diyakini dapat memberikan perlindungan dan rasa nyaman pada masyarakat dalam menjalani hidupnya. Berikut ini adalah jenis-jenis kekarangan.

\section{Karang Guak/Manuk}

Karang guak sebagai stilisasi kepala burung terkait dengan mitos tentang sifat dan tugas burung sebagai penjaga dunia atas. Mitologi maupun keyakinan rakyat yang disampaikan secara oral tentang keperkasaan ataupun ketangguhan burung dalam menjaga kedamaian dunia. Ini dapat dijumpai dalam ceritera seperti lahirnya Garuda, Bhomantaka, dan Tantri Kamandaka. Pada setiap ceritera tersebut, burung mempunyai arti tersendiri, yaitu sebagai lambang yang mengandung multi nilai seperti nilai pendidikan, budi pekerti susila dan yang lainnya.

Motif karang guak mempunyai tempat paling atas dalam badan bangunan bade yaitu pada waton. Perlu pula diketahui, struktur bagungan bade dapat di bagi menjadi tiga bagian yaitu bagian atas berupa atap yang lasim disebut tumpang. Bagian badan yang dalam dunia perundagian disebut dengan palih mulai dari palih wayah, made, nyoman dan palih ketut. Hitungan atau nama-nama palih ada juga yang menyebutnya seperti palih bukur, taman, sancak, bacem. Selain itu, untuk setiap palih mempunyai bagian atau pekaad yang disebut dengan pelok.

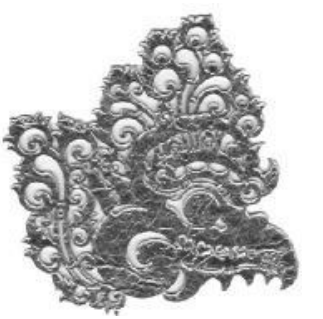

No. 15. Motif Hias Karang Guak. (Tatahan: I Made Suparta) 
Begitu pula burung garuda dan burung merpati oleh umat tertentu dijadikan lambang perdamaian. Motif karang guak/manuk biasa ditempatkan pada bagian atas sudut-sudut bangunan baik itu bangunan tempat suci maupun tempat tinggal. Selain itu motif ini juga biasa menghiasi canggah wang (sikusiku yang menghubungkan tiang dengan lambang pada suatu bangunan.

\section{Karang Tape!}

Karang tapel pada bangunan bade ditempatkan pada bagian tengah dalam badan bangunan. Perbedaan bentuk antara karang tapel dengan karang guak terletak pada bagian gigi dan bentuk daun telinga. Kalau karang guak bentuk gigi dan daun telingan agak runcing/lancip, sedangkan karang tapel agak rata/tapak.

Tapel atau topeng, yang artinya alat peraga penutup muka bagi penari (dramatari topeng) oleh para kriyawan divisualisasikan berupa motif hias dengan maksud memperindah suatu ruang atau bidang. Motif hias yang menstilisasikan bentuk muka manusia ini banyak menghiasi bangunan-bangunan tradisional Bali, dan mempunyai perbedaan yang signifikan dalam menggunakan unsur motif untuk suatu pola.
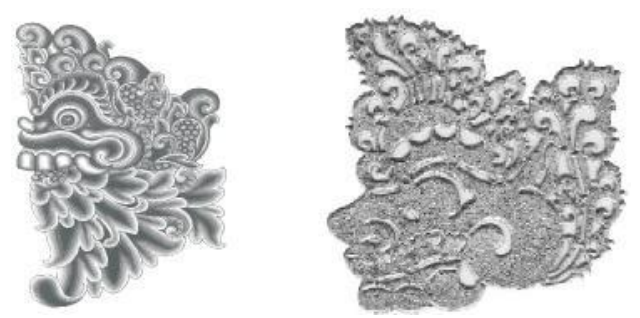

No. 16. Motif Hias Karang Tape!.

(Gambar: I Gusti Ngurah Agung Jaya

CK) (Tatahan: I Made Suparta)

\section{Karang Bentu! u}

Motif hias karang bentulu, kalau dilihat dari bentuk pola dan unsur motif yang digunakan, tidak jauh berbeda dengan motif hias karang tapel. Adapun yang membedakan antara karang tapel dan karang bentulu, adalah dari segi penempatan, jumlah mata, dan tidak berhidung. Penempatan kekarangan yang satu ini, tidak pada sudut bangunan, melainkan untuk menghiasi bidang tengah yang kosong di antara kekarangan-kekarangan yang ada di setiap sudut bangunan bade atau lainnya . Unsur pokok motif hias karang bentulu seperti satu mata, gigi, taring, gusi, pipi, bibir, telinga, dan alis. Motif kekarangan ini dihiasi dengan motif pepatran yaitu patra punggel.
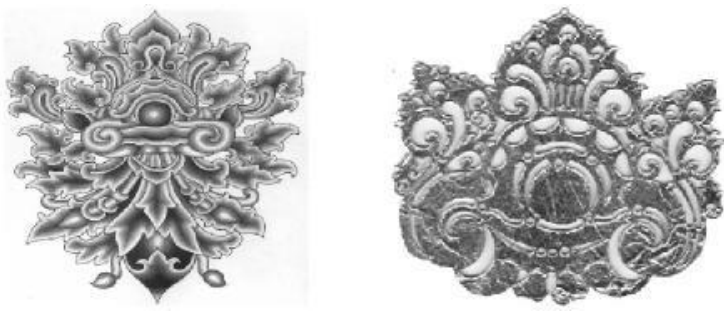

No. 17. Motif Hias Karang Bentu!u.

(Gambar: I Putu Diarmo)

(Tatahan: I Made Suparta)

\section{Karang Asti}

Karang asti atau karang gajah dalam seni hias-menghias ditempatkan pada bagian dasar (bhur loka) suatu bangunan. Secara fisik binatang gajah mempunyai badan dan kekuatan besar, gading yang menawan, telinga besar namun beberapa bagian badannya ada kelucuan, misalnya ekornya kecil. Belalai, sepasang gading dan telinga yang besar melambai bagaikan daya magnet yang dapat menarik inspirasi para kriyawanatau undagi untuk menjadikannya motif hias.

Selain pertimbangan estetis, secara teknis juga menjadi perhatian dalam pembuatan karang asti/gajah ini, pertimbangan teknis ini berdasarkan penempatan karang gajah paling bawah pada badan bade yang rawan sentuhan dengan karang bhoma atau paksi begitu juga naga yang biasanya memerlukan tempat yang agak lebar. Yang paling rawan, penempatan karang asti ini di atas sanan, yaitu bambu yang digunakan untuk memikul /mengusung bangunan.

Motif hias karang asti yang ditempatkan pada bagian bawah suatu bangunan dengan mengutip cerita Sutasoma dan lahirnya Ganesha. Dalam hal itu diceritakan, bahwa Gajah Waktra memiliki kesaktian yang tidak dapat dikalahkan atau dibunuh oleh para Dewa, raksasa, apalagi manusia. Semua kekuatan dan kesaktian Gajah Waktra diperoleh berkat anugerah Bhatara Ghana, sejak itu Gajah Waktra menjadi Raksasa Durmuka, yaitu manusia berkepala gajah dan memiliki empat tangan. Raksasa Durmuka semakin hari kian buas dan membunuh siapa saja yang berani melintasi hutan tempat tinggalnya yang menyebabkan para pertapa/rsi merasa cemas. Adalah Sutasoma, inkarnasi Budha, dapat menyadarkan segala perbuatan dosa yang pernah dilakukan Durmuka dengan senjata bajra. Senjata bajra menindih dan merasuki jiwa Durmuka yang mampu melenyapkan sifat-sifat keangkaramurkaan yang telah lama melekat pada dirinya. Durmuka tertindih tidak karena beratnya senjata bajra, namun berat itu terjadi karena kebesaran hati dan luasnya pengetahuan tentang Budha yang disatukan lewat senjata bajra. (Team Penyusun Naskah-naskah Satua Bali, 1985:38-68). 
Seorang raksasa begitu tekun dan teguhnya melakukan tapa yoga samadi, sehingga hati Batara Siwa merasa terketuk untuk menganugerah kesaktian yang tidak terkalahkan oleh para Dewa sekalipun. Suatu ketika raksasa itu ingin menyerang sorga loka, yang menyebabkan ketakutan di kalangan para dewa. Kesaktian yang dimiliki raksasa tersebut diketahui oleh Dewa Indra berkat anugerah Dewa Siwa. Dewa Indra diikuti segenap Dewa lainnya memohon kemurahan hati Dewa Siwa untuk menciptakan mahluk yang dapat mengalahkan raksasa Asura. Dewa Siwa sendiri tidak berani ingkar janji terhadap raksasa yang telah diberi kekuatan dan menyerahkannya satu lagi kekuatannya berupa seorang pemuda tampan lewat diri Parvati yang diberi nama Vighnesvara. Putra Parvati amat tampan, semua Dewa berlama-lama ingin melihatnya, di antara Dewa-Dewi itu ada seorang yang tidak berani melihat ketampanan Vighnesvara, yakni San (Saturnus). Ketidakberaniannya melihat Vighnesvara itu akibat kena kutuk, apapun yang dilihat akan hancur.
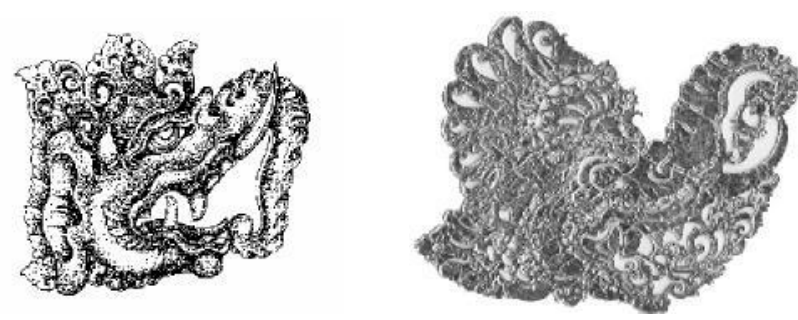

No. 18. Motif Hias Karang Asti.

(Gambar/Tatahan: I Made Suparta)

Parvati meyakinkan pada Sani, hal itu tidak akan terjadi pada anaknya Dengan berat hati Sani melihat dan di luar dugaan, kepala Vighnesvara hancur menjadi abu. Brahma menghibur hati Parvati dengan mengatakan kepala binatang yang pertama dilihat akan dijadikan sebagai penggantinya. Ketika Wisnu sedang terbang naik Garuda, ia melihat ada seekor gajah, kemudian ia memenggal kepalanya untuk diletakkan pada leher Vighnesvara. Setelah kejadian itu Vighnesvara diberi nama Ganesha. Itulah ceritera di balik karang asti.Karang asti/gajah, terdiri sepasang mata bulat/sipit, telinga lebar, gigi runcing/tumpul, menggunakan rahang bawah, gading dan berbelalai panjang/pendek. Kekarangan ini biasanya diletakkan pada sudut bagian bawah bangunan. Adapun karang bentulu/karang mata adalah kekarangan yang menggunakan hanya satu mata bulat dengan gigi tumpul dan sepasang telinga. Jenis kekarangan ini biasanya ditempatkan pada badan bangunan (di tengah-tengah), tidak pada sudut bangunan.

\section{Karang Paksi}

Dilihat dari posisi tempat, karang paksi atau garuda maupun karang bhoma sama-sama berada di bagian bawah badan bade. Karang bhoma berada di bagian depan bangunan bade, sedangkan karang paksi berada di bagian belakang bangunan bade. Motif hias paksi/garuda selain menggunakan unsur motif seperti mata bulat mulut runcung, gigi beserta taring runcing, bagian kepala dihiasi gelung/mahkota.

Seperti yang diungkapkan di atas, Bali mempunyai budaya yang sangat beragam pada setiap daerahnya, turut serta penempatan garuda disesuaikan dengan desa, kala, dan patra. Untuk di daerah Payangan Gianyar tempat diadakannya penelitian ini, penempatn karang Garuda berada di bagian belakang bangunan bade. Sedangakan di Daerah Karangasen yang juga dijadikan popolasi dalam penelitian ini, karang Garuda ditempatkan pada bagian depan bade. Keyakinan dan kepercayaan terhadap babab yang memeng memuatan tentang kelengkapan dan penempatan suatu motif hias kadang kala dikalahkan oleh adat kebiasaan yang diwariskan secara turun-temurun.

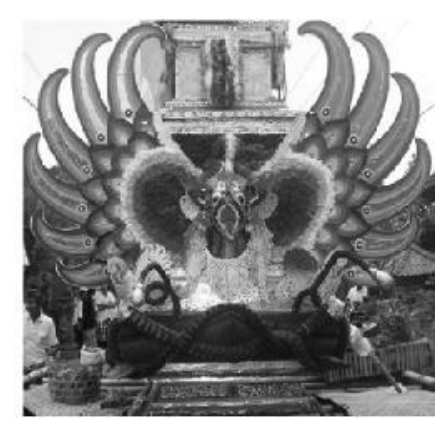

\section{No. 19. Motif hias Karang paksi/garudayang berada pada bagian} belakang bangunan bade (Tatahan: I Made Suparta)

\section{Karang Bhoma}

Motif hias karang bhoma mempunyai perbedaan yang cukup signifikan, dengan motif hias lainnya. Keplastisan motif ini begitu kentara selain dukungan tempat yang strategis, karena terdapat bagian depan bade, dan memiliki ukuran yang besar sehingga motif hias karang bhoma tampak tunggal dan menonjol.

Kekarangan sebagai hasil olah stilisasi bentuk oleh para perupa kriya terhadap berbagai macam binatang yang tergolong herbivora, karnivora dan omnivora, telah menjadi bagian penting dan tidak terpisahkan dalam kehidupan beragama di Bali. 


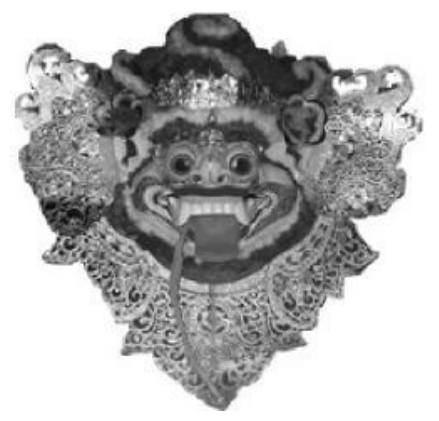

No. 20. Karang Bhoma pada bangunan bade dengan menggunakan hiasan senjata cakra pada tangan kanan, dan senjata trisula pada tangan kiri. (Karya:I Made Suparta)

Motif hias kekarangan adalah kombinasi dari beberapa bagian motif tokoh Raksasa dan Dewa yang distilisasi dan ditata untuk mendapatkan bentuk yang mendekati bentuk ideal. Motif hias Karang Bhoma ada yang berpendapat sebagai hasil stilisasi binatang hutan dengan sepasang mata yang bundar, mulut menganga, tangan terbuka, di atas dahi terdapat karang batu dan ada pula menggunakan mahkota, pada kening terdapat karang bajra, kedua telinga berhiaskan kembang sepatu, dan disertai dengan bentuk gigi maupun taring yang tumpul.

Semua jenis kekarangan yang ada di Bali, agar kelihatan lebih harmonis, selalu dipadukan dengan patra-patra yang dianggap mendukung, misalnya karang sae dengan patra cina, karang gajah/asti dengan patra punggel. Seperti yang telah diungkapkan dia atas, Kekarangan yang mempunyai kata dasar karang mengandung arti tempat, awalan ke- dan akhiran -an pada kata karang sebagai kata pasif yang menunjukkan benda. Benda yang dimaksud dalam hal ini berupa benda mati maupun makhluk hidup, yang bergerak maupun yang diam. Wayan Pugeg setuju, walaupun tidak membenarkan, bahwa motif hias karang bhoma yang ada pada bangunan bade berasal dari stilisasi binatang macan. Kesetujuannya ini dikarenakan Bade sebagai personivikasi gunung yang dihuni oleh macan/singa. Berkat adanya macan/singa sebagai penghuni hutan, keselamatan dan kelestarian hutan berserta isinya lebih aman dari tindakan manusia yang ceroboh dan tidak bertangung jawab. Seniman yang serba bisa dan merasa paling bahagia menekuni seni togog ini, tidak mempunyai pilihan lain selain merujuk Kakawin Naraka Wijaya/ Bhomantaka ketika ia membuat Bhoma (karang bhoma). Karang Bhoma adalah kekarangan yang paling disakralkan dibandingkan kekarangan lainnya Kekarangan itu (bhoma) pantas ditempatkan di bagian depan atau belakang bade (sesuai desa kala dan patra) sebagai salah satu sarana untuk mengantarkan roh ke sorga. Sesepuh seni togog asal Singapadu ini juga mengingatkan, kalau membuat karang bhoma di mana dan apapun tujuannya, harus dilakukan oleh orang yang sudah mawinten, disertai dengan sesaji daksina sebagai atur piuning (pemberitahuan) kepada Wiswakarma, yaitu Dewanya para undagi/sangging, dengan tujuan untuk mendapatkan keselamatan dalam bekerja membuat mиa (muka) sebagai sarana pemujaan yang disakralkanI (Wayan Pugeg, "Wawancara", 21 April 2008, di Singapadu, Gianyar).

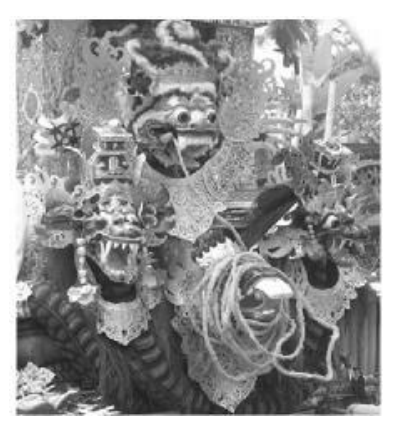

Gambar No. 21. Bagian depan dari bangunan bade yang terdiri dari motif bhoma, dua ekor naga, dan empas. (Karya: I Made Suparta)

Kalau dilihat dari unsur pola dan bentuk motif hias karang bhoma sama sekali tidak menampakkan stilisasi golongan binatang yang disebut di atas. Mite motif-motif hias karang bhoma ada juga yang mengatakan sebagai stilisasi binatang macan, walaupun mite itu belum dijumpai secara tertulis seperti misalnya dalam bentuk kakawin maupun gaguritan Menurut I Made Sidja, seorang seniman yang aktif menekuni bidang seni pertunjukan, seni sastra, dan seni rupa, mengatakan Bhoma berasal dari dua kata yaitu bahu dan тиa, yang mempunyai arti tangan dan mulut. Oleh karena mulut adalah bagian dari muka, maka pengertian muka dan sering juga diartikan kepala. Bhoma adalah kekarangan yang tidak berdiri sendiri, banyak dihiasi oleh motif-motif lainnya.(I Made Sidja, "Wawancara", 21 September 2008, Bona Gianyar).

Dalam Kamus Jawa-Kuna, kata bahu juga berarti tangan. Sesuai dengan penulisan ini, bhoma dapat diartikan sebuah motif hias yang menggunakan dua sruktur pokok/isi, yaitu muka dan tangan, yang didukung oleh unsur-unsur dan struktur serta jenis motif lainnya. Struktur terbentuk lewat serangkaian unsur, namun unsur-unsur itu mengikuti dan tunduk kepada kaidah-kaidah yang mencirikan suatu sistem. Sistem tersebut berkaitan dengan kaidah-kaidah, yakni kaidah komposisi yang secara tidak langsung membangkitkan asosiasi komulatif, tetapi menyertakan sifat-sifat himpunan yang berbeda dari sifat unsur-unsurnya. 
Naga

Motif hias naga adalah suatu bentuk motif yang diciptakan berdasarkan realita ataupun mitos tentang makhluk-makhluk kayangan dan dewa-dewa dengan berbagai statusnya serta totem-totem yang diyakini keberadaannya. Motif naga sering dijadikan hiasan pada sebelah kiri-kanan tangga pada candi, tempat ibadah (Hindu) dan dalam bentuk panil/relief. Di Bali, setiap daerah memiliki motif naga sendiri, seperti motif naga gaya gianyar, badung dn derah lainnya di Bali. Motif hias naga ini biasanya dibuat secara berpasangan yang menggambarkan naga Basuki dan Ananta Boga. Dalam beberapa sumber, naga adalah pembelit/pengikat gunung sewaktu pemutaran gunung mendara giri.

Dilihat dari segi pewarnaan, warna basuki dengan warna hijau, dan ananta boga warna merah. Motif hias naga ini selalu ditempatkan pada bagian depan bade dengan posisi mengapit Bedawang atau empas.

Empas

Empas atau sering juga disebut dengan bedawangnala adalah seekor kurakura besar sebagai Awatara Wisnu yang disebut dengan Kurma Awatarar. Empas digambarkan digambarkan dengan sepasang mata, dua buah gigi tanpa taring dan dari lidahnya keluar api sebagai simbol panasnya bumi. Dilihat dari bentuknya, empas mempunyai bentuk yang paling sederhana diantara kekarangan lainnya Karang Empas menempati posisi paling bawah dalam badan bade.

\section{SIMPULAN DAN SARAN}

\section{Simpulan}

Tradisi menggunakan bade dalam upacara ngaben yang dilakukan secara berkelanjutan bagaikan lingkaran ekosistem yang satu sama lainnya saling membutuhkan. Dalam upaya melestarikan dan memberdayagunakan tradis penggunaan motif hias dalam bade pada sisi tertentu sangat ketat pada aturan yang tertuang pada babad. Dan pada sisi lainnya masyarakat hindu Bali juga selektif adaptif tanpa mengabaikan nilai-nilai agama, keseimbangan, solidaritas, estetika keindahan, dan kebenaran. Di balik sifat ketradisiannya yang kuat, Bali juga mempunyai agresifitas dalam menyikapi keadaan untuki memelihara sekaligus mengembangkan seni budayanya dan tradisi yang ada.

Motif hias yang beragam dan dijadikan motif bagian pada bangunan bade, tetap memiliki nilai sakral dan akan berlanjut semasih warna/kasta mentaati tradisi leluhurnya serta kewenangan yang diberikan oleh Dalem (raja) Dengan kata lain, semasih acara ngaben menggunkan sarana bade, motif hias dengan berbagai jenis dan bentuknya tetap diperlukan.

Motif hias yang ada pada bangunan bade, memiliki hubungan hierarkis yang ganda sesuai dengan konsep desa kala patra. Penempatan motif hias yang ada pada bade adalah bentuk hubungan hirarkis horizontal di antara warna/kasta dalam agama Hindu terhadap Dalem (raja) atas penghargaan yang pernah diberikan. Tugas dan kewajiban itu sampai sekarang masih tetap dilaksanakan oleh umat Hindu Dharma di Bali.

Tradisi kuat untuk menjalankan aturan-aturan yang diwariskan, dan termuat dalam Motif hias sebagai salah satu bagian yang esensial pada bangunan bade, telah dijadikan sarana dan simbol oleh umat Hindu Dharma di Bali untuk mencapai keselarasan hidup lewat hubungan vertikal maupun horizontal. Unsurunsur yang terdiri dari beberapa motif dan terhimpun membentuk motif hias keketusan, pepetran maupun kekarangan adalah sebagai kesatuan yang selaras untuk setiap golongan (stratifikasi) yang ada. Pengertian motif hias, telah membias dan melandasi pemanfaatan berbagai macam, jenis, dan teknik tatahan yang ada pada bangunan bade.

Teknik tatahan yang ada pada hampir setiap motif hias nyaris atau ada kecenderungan sama denga yang adapada tatahan wayang kulit maupun barong yang didominasi oleh patra punggel dan jenis keketusan. Kesatuan atau totalitas yang ada pada setiap inti motif hias, bukan merupakan suatu gabungan, yang terjadi adalah himpunan tertata dari beberapa macam dan jenis motif yang ada, digunakan untuk memperkaya atau melengkapinya.

\section{Saran}

Pengkaderan atau kaderisasi sangging sangatlah perlu dan mendesak dilakukan, mengingat Bali yang penduduknya mayoritas beragama Hindu Dharma, banyak menggunakan karya-karya seni rupa yang dijadikan sarana keagamaan. Untuk menghindari hal-hal yang tidak diinginkan dalam pembuatan atau selama menggunakan motif hias khususnya yang disakralkan, para kriyawan diharapkan lebih aktif mencari tahu kewajibannya sehingga pada saatnya nanti bisa menjadi undagi.

Kendati masyarakat Bali, khususnya para undagi atau kriyawan menggunakan konsep rwa bhineda dan desa, kala, patra dalam membuat dan menggunakan motif hias pada bangunan bade tetap perlu adanya satu kesatuan persepsi yang baku untuk menentukan struktur unsur-unsur motif inti secara hirarki dalam penemptannya pada suatu bangunan yang disebut bade.

\section{DAFTAR PUSTAKA}

Daeng, Hans J., 2000. Manusia, Kebudayaan dan Lingkungan Tinjauan Antropologi, Yogyakarta: Pustaka Pelajar.

Griya Tengah. Tanpa Tahun. "Pyagem Pulesari”. Terjemahan Ida I Dewa Gde Catra. 
SP. Gustami. 1983/1984. "Seni Ukir dan Masalahnya", Yogyakarta: STSRI "ASRI.

Maulana, Ratnaesih. 1997. Ikonografi Hindu. Jakarta: Fakultas sastra Univesitas Indonesia.

Patra, Made Susila. 1992. Hubungan Seni bangunan Dengan Hiasan Dalam Rumah Tempat Tinggal Adat Bali. Jakarta: Balai Pustaka.

Purnatha. 1976/1977. Sekitar Perkembangan Seni Rupa di Bali. Denpasar: Proyek Sasana Budaya Bali.

Paz, Oktavio. 1997. Levi Strauss Empu Antropologi Struktural. Terjemahan Landung Simatupang. Yogyakarta, LKIS.

Sika, I Wayan, 1983, Pengenalan Ragam Hias Bali. Jakarta: Pembinaan Sekolah Menengah Kesenian Direktorat P.M.K. Ditjen P.D.M. Dep. P dan K.

Singarimbun, Masri. 1989. Metode dan Proses Penelitian, Metode Penelitian Survey. (Ed. Masri Singarimbun dan Sofian Effendi). Jakarta; LP3ES.

Soekiman, Djoko. 2000. Kebudayaan Indis dan gaya Hidup Masyarakat Pendukungnya di Jawa (Abad XVII - Medio Abad XX). Yogyakarta: Bentang.

SP. Gustami, 1983/1984, "Seni Ukir dan Masalahnya”, Yogyakarta: STSRI “ASRI

Sudara I Gusti Nyoman dan Nikanaya I Nyoman, 1983, "Kumpulan Ornamen

Kumpulan Pola Hias Bali”. Denpasar: Sekolah Menengah Seni Rupa Negeri Denpasar SMSR.

Sutrisno Hadi, 986. Bimbingan Menulis Skripsi Tesis. Jilid I. Yogyakarta: Yayasan Penerbit Fakultas sastra Psikologi Universitas Gajah Madha.

Team Penyusun Naskah-naskah Satua Bali, 1985, Sutasoma, Denpasar: PEMDA Tingkat I Bali, Proyek Penyusunan Naskah dan Percetakan Buku-buku Pelajaran Daerah Tingkat I Bali.

Tim Ahli Penelitian dan Pencatatan Kebudayaan Daerah Bali. 1977. Adat Istiadat Daerah Bali. Jakarta: Proyek Pengembangan Media Kebudayaan Departemen Pendidikan dan Kebudayaan.

Tim Penyusun Kamus Pusat pembinaan dan Pengembangan Bahasa, 1989. Kamus Besar Bahasa Indonesia. Departemen Pendidikan dan Kebudayaan. Jakarta, Balai Pustaka.

Titib, I Made. 2001. Teologi dan Simbol-simbol dalam Agama Hindu; Surabaya: Paramita bekerjasama dengan Badan Litbang Parisada Hindu Dharma Indonesia Pusat.

Van der Hoop. 1949. Indonesische Stiermotieven, Bandung: N.V. Uitgeverij W. Van Houve, Bandung s' Gravenhage.

Wardana, I Made. 1993/1994, Topeng Koleksi Museum NegeriPropinsi Bali, Denpasar: Departemen Pendidikan dan Kebudayaan Direktorat Jenderal Kebudayaan, Bagian Proyek Pembinaan Permuseuman Bali. 